\title{
Expression of Nestin, CD133 and Sox2 in Meningiomas
}

\author{
Zong-Yu XIAO'1, Xiao-Juan CHEN², Qi PAN${ }^{3}$, Qing-Zhi YANG ${ }^{1}$, Kun-Zheng LI ${ }^{1}$ \\ ${ }^{1}$ Affiliated Hospital of Qinghai University, Department of Neurosurgery, Xining City, China \\ ${ }^{2}$ Qinghai People's Provincial Hospital, Department of Neurology, Xining City, China \\ ${ }^{3}$ Affiliated Hospital of Hainan Medical College, Department of Neurosurgery, Haikou City, China
}

\section{ABSTRACT}

AIM: To investigate the expression of cancer stem cell markers in meningiomas.

MATERIAL and METHODS: CD133, Nestin and Sox2 expression levels in 35 paraffin-embedded meningioma tissue samples were assessed using immunohistochemistry.

RESULTS: In this study, five cases were atypical (WHO Grade II), two were anaplastic (WHO Grade III), and 28 were benign (WHO Grade I). Among atypical and anaplastic meningiomas, all were positive for Nestin and CD133, and 4 were positive for Sox2. Of the 28 benign meningiomas, 23 were positive for Nestin, 11 were positive for CD133, and none were positive for Sox2. In addition, Nestin and CD133 were expressed at significantly higher levels in the non-benign group than in the benign group.

CONCLUSION: Nestin, CD133 and Sox2 expression levels may be correlated with the WHO pathological grade. Specifically, more aggressive meningiomas are characterized by higher positivity rates and higher levels of Nestin, CD133 and Sox2 expression in positive cells.

KEYWORDS: Meningioma, Nestin, CD133, Sox2

\section{INTRODUCTION}

$\mathrm{M}$ eningioma, the most common type of primary benign tumor in the central nervous system, accounts for approximately one-third of all brain tumors (2). Meningiomas are classified into the following World Health Organization (WHO) grades: benign (Grade I), atypical (Grade II) and malignant (Grade III) (21). Grade I meningiomas are usually treated with surgery, which achieves good results. However, Grade II and Grade III meningiomas are more likely to behave aggressively and have higher recurrence rates $(7,33)$. In most cancers, cancer stem cells (CSCs), a subpopulation of cancer cells that have the ability to self-renew and differentiate, may play critical roles in tumor initiation, progression and prognosis; in brain tumors, CSCs are also known as brain tumor stem cells (BTSCs), and BTSCs have been successfully isolated in many types of brain tumors and brain tumor cell lines $(10,11,16,20,24)$. However, whether BTSCs are present in meningiomas is unclear. In this study, we investigated the expression of BTSC markers in meningiomas.

\section{MATERIAL and METHODS}

\section{Tissue Samples}

Thirty-five paraffin-embedded meningioma tissues were obtained from the Department of Neurosurgery of the Affiliated Hospital of Qinghai University. The tumor sections were reviewed by two neuropathologists to verify the diagnosis of meningioma in accordance with the 2016 WHO classification of central nervous system tumors (7). According to these criteria, meningiomas are classified into the following $\mathrm{WHO}$ grades: benign (Grade I), atypical (Grade II), and anaplastic (Grade III). The 35 meningioma tissues were divided into the following groups: benign (Grade I) and non-benign (Grade II and Grade III). The stem cell markers Nestin, CD133, and sex- 
determining region $Y$ (SRY)-box 2 (Sox2) were analyzed in all tissue samples using immunohistochemistry. This study was approved by the Research Ethics Committee of the Affiliated Hospital of Qinghai University. Written informed consent was obtained from the families.

\section{Immunohistochemistry}

Tissue sections were prepared using a previously described method to investigate the expression of the stem cell markers Nestin, CD133, and Sox2 (11). Slides were incubated with anti-Nestin (Millipore, catalog number: ABD69, dilution 1:100), anti-CD133 (NOVUS, catalog number: NB120-16518, dilution 1:100) and anti-Sox2 (Millipore, catalog number: MAB4343, dilution 1:100) antibodies overnight at $4^{\circ} \mathrm{C}$. After the slides were washed with phosphate-buffered saline (PBS), they were treated with PowerVision Two-Step Histostaining Reagent (Zhongshan Goldenbridge Biotechnology, catalog number: PV-9000) for 30 minutes at $37^{\circ} \mathrm{C}$. The chromogen used to label positive reactions was 3,3'-diaminebenzidine tetrahydrochloride (DAB), which appears as a brown stain. Next, the slides were counterstained with Mayer's hematoxylin. Finally, the slides were covered with permanent mounting medium, and each section was photographed in 20 random fields at $400 \times$ magnification. CD133, Nestin, and Sox2 expression in meningioma sections was semi-quantitatively evaluated using Image-Pro Plus (Media Cybernetics, Silver Spring, MD) by measuring the integrated optical density (IOD) of the signal.

\section{Statistical Analysis}

Analysis was performed using SPSS 22.0 (SPSS, Inc., Chicago, IL, USA). The differences in Nestin, CD133 and Sox2 expression levels in the benign and non-benign groups were analyzed using Mann-Whitney test. A p value less than 0.05 was considered as statistically significant.

\section{RESULTS}

Tissues from 6 males and 29 females were examined (mean age $=50.49 \pm 11.55$ years, range $=22$ to 70 years). Five tissues were atypical (Grade II, WHO), two were anaplastic (Grade III, WHO), and 28 were benign (Grade I, WHO). The 35 tissues were primary meningiomas that had not been previously treated. All atypical and anaplastic meningiomas were positive for Nestin and CD133, and 4 (57.12\%) were positive for Sox2. Of the 28 benign meningiomas, 23 (82.14\%) were positive for Nestin, 11 (39.29\%) were positive for CD133, and none were positive for Sox2 (Table I). Moreover, the mean IODs of Nestin and CD133 were significantly higher in the non-benign group than in the benign group $(p=0.001)$ (Figure $1 \mathrm{~A}-\mathrm{F})$.

\section{DISCUSSION}

Over the past few decades, numerous studies have documented the presence of CSCs in many types of brain tumors and tumor cell lines, including glioblastoma (GBM), medulloblastoma, ependymoma and both the C6 and 9L cell lines; CSCs are also known as BTSCs in brain tumors $(10,11,16,20,24)$. CSCs are a subpopulation of tumor cells that can self-renew and extensively proliferate, are pluripotent, and can initiate tumorigenesis; these properties may play critical roles in tumor initiation, progression and recurrence $(16,24)$.

Meningiomas are the most common benign tumors in the central nervous system (2). Based on their pathological characteristics, the majority of meningiomas are benign, although some are malignant. Benign meningiomas are often treated with good results, but recurrence is very common among most malignant meningiomas. Moreover, some benign meningiomas can recur even after total resection and excision of the dura and affected bone (9). Therefore, we presume that meningioma tumor stem cells may be responsible for these events. According to recent reports, CSC-like cells may be present in meningiomas $(13,17,30)$. Traditionally, Nestin, CD133 and Sox2 are regarded as CSC markers, but they could also be considered specific markers for BTSCs (28). In this study, we investigated the expression of Nestin, CD133 and Sox2 in meningiomas.

Nestin is a class six intermediate filament protein expressed in neural stem cells and BTSCs. Galani et al. investigated the expression of Nestin in 17 patients with meningiomas using qRT-PCR and found that Nestin was expressed at higher levels in atypical and anaplastic meningiomas than in benign meningiomas (9). In the present study, all atypical and anaplastic meningiomas as well as the majority of benign meningiomas were positive for Nestin. However, Nestin was expressed at higher levels in non-benign meningiomas than in benign meningiomas, consistent with the results reported by Galani et al. However, Nestin expression is not a specific marker for BTSCs (12); thus, the identification of more markers is needed in the study.

Prominin-1 (PROM-1), also known as CD133, is a protein with several isoforms with unknown physiological or pathological function that is expressed in both the cytoplasm and at the cell surface $(22,32)$. CSCs in gliomas were first isolated by Singh et al.; they showed that only CD133-positive glioma cells have the characteristics of self-renewal, extensive proliferation, pluripotency and tumorigenesis initiation (26). According to Singh et al., $100 \mathrm{CD} 133+$ cells are sufficient to initiate brain tumors in non-obese diabetic (NOD)/severe combined immunodeficient (SCID) mice, whereas 100,000 CD133-

Table I: Expression of CD133, Nestin and Sox2 in Meningiomas

\begin{tabular}{lcccc}
\hline \multirow{2}{*}{ Name } & $\begin{array}{c}\text { Total meningiomas } \\
(\mathbf{n}=\mathbf{3 5})\end{array}$ & Benign $(\mathbf{n}=\mathbf{2 8})$ & Atypical $(\mathbf{n}=\mathbf{5})$ & Anaplastic $(\mathbf{n}=\mathbf{2})$ \\
\cline { 3 - 5 } & 18 & 11 & 5 & 2 \\
\hline CD133 & 30 & 23 & 5 & 2 \\
\hline Nestin & 4 & 0 & 2 & 2 \\
\hline Sox2 & & & & \\
\hline
\end{tabular}


cells do not form tumors. Moreover, CD133 expression is an important prognostic marker in glioma, lung cancer, colorectal cancer and other cancer types $(5,6,14,18,19,23,31)$. Recently, Tang et al. successfully isolated meningioma cells from six patients and showed that CD133 expression levels were related to cell proliferation rates (30). Therefore, CD133 is regarded as a specific marker of BTSCs in malignant brain tumors (26). In the present study, all WHO Grade II and III meningiomas were positive for CD133, whereas only 11 benign meningiomas were positive for CD133. Moreover, CD133 was expressed at much higher levels in the non-benign tumor group, and the rate of CD133 positivity was significantly lower than the rate of Nestin positivity, suggesting that CD133 is a better CSC marker for meningioma than Nestin. However, some CD133cells also have BTSC properties. Beier et al. showed that some CD133- cells isolated from GBM were also tumorigenic in T-lymphocyte-deficient NMRI (nu/nu) mice (4). Joo et al. demonstrated that CD133+ and CD133- cells purified from GBM could initiate GBM-like tumors in NOD/SCID mice (15). Therefore, CD133 may not be a specific marker for BTSCs.

Sox2 is a transcription factor that plays a critical role in the maintenance of the self-renewal capability of neural stem cells, and its activity is associated with the maintenance of the undifferentiated state of CSCs in several tissues $(1,3,8)$. Ghods et al. demonstrated that $29.9 \% \pm 3.8 \%$ of $9 \mathrm{~L}$ glioma stem cells are Sox2 positive, whereas 9L glioma cells are Sox2 negative (11). Several groups have detected increased Sox2 levels in biopsies from patients with GBM, and the highest levels are associated with a poor outcome (25). Other researchers found that Sox2 is the most enriched gene among the stemness signature in CD133+ GBM cells. Overexpression of Sox2

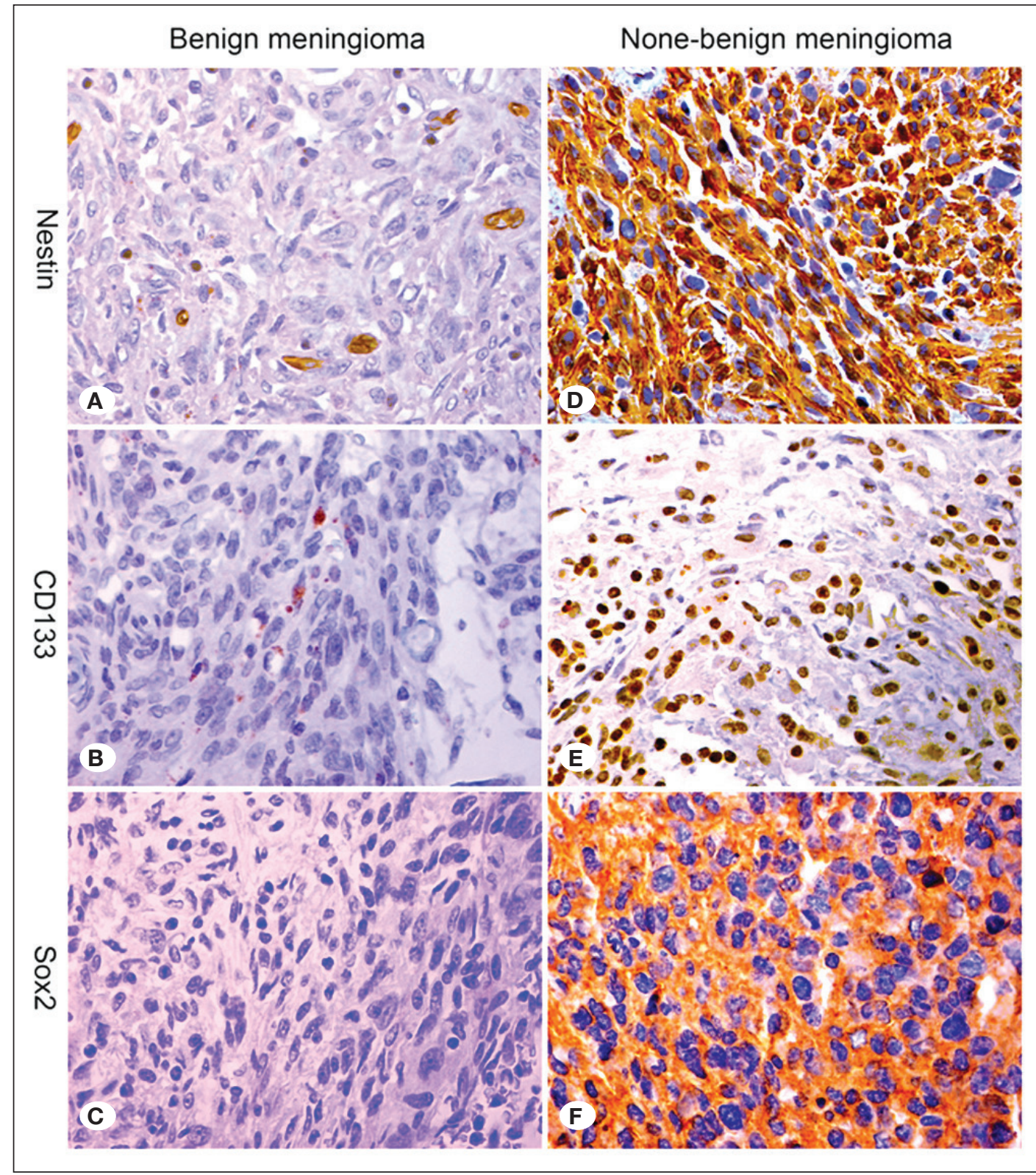

Figure 1: Expression of Nestin, CD133 and Sox2 in benign (A, B, and $\mathrm{C})$ and non-benign meningiomas (D, E, and F), as measured by immunohistochemistry $(\times 400)$. 
consistently enhances stem cell potency in GBM cell lines, whereas knockdown of Sox2 dramatically reduces CD133 expression and eliminates tumor initiation ability and drug resistance in CD133+ GBM cells (27). Therefore, Sox2 plays a crucial role in regulating tumorigenicity in CD133+ GBM cells and is regarded as a functional marker for BTSCs (29). In the present study, none of the benign meningiomas were positive for Sox2, and only 4 non-benign meningiomas were positive for this marker.

This study has several limitations. Although 35 cases of meningioma were included in our study, only 7 were WHO Grade II or III. Therefore, further investigations of larger numbers of meningioma cases are needed.

In the present study, none of the benign Meningiomas were positive for Sox2, and only 4 non-benign meningiomas were positive for this marker. The rate of Sox2 expression was significantly lower than the rates of CD133 and Nestin expression.

\section{CONCLUSION}

Nestin, CD133 and Sox2 expression levels may be correlated with the WHO pathological grade. Specifically, more aggressive meningiomas are characterized by higher positivity rates and higher levels of Nestin, CD133 and Sox2 expression in positive cells.

\section{ACKNOWLEDGMENT}

We thank Fengmei Wang (Department of Pathology, Affiliated Hospital of Qinghai University) for assisting with immunohistochemistry. The project was supported by the Youth Foundation of the Natural Science Foundation of Qinghai Province (2015-ZJ-943Q), the Youth Foundation of the Qinghai University (2014-QYY-6), and the Youth Foundation of the Affiliated Hospital of Qinghai University (ASRF-2015ZD-01).

\section{- REFERENCES}

1. Acanda de la Rocha AM, Lopez-Bertoni H, Guruceaga E, Gonzalez-Huarriz M, Martinez-Velez N, Xipell E, Fueyo J, Gomez-Manzano C, Alonso MM: Analysis of SOX2-regulated transcriptome in glioma stem cells. PLoS One 11: e0163155, 2016

2. Alexiou GA, Gogou P, Markoula S, Kyritsis AP: Management of meningiomas. Clin Neurol Neurosurg 112: 177-182, 2010

3. Annovazzi L, Mellai M, Caldera V, Valente G, Schiffer D: SOX2 expression and amplification in gliomas and glioma cell lines. Cancer Genom Proteom 8: 139-147, 2011

4. Beier D, Hau P, Proescholdt M, Lohmeier A, Wischhusen J, Oefner PJ, Aigner L, Brawanski A, Bogdahn U, Beier CP: CD133(+) and CD133(-) glioblastoma-derived cancer stem cells show differential growth characteristics and molecular profiles. Cancer Res 67: 4010-4015, 2007

5. Beier D, Wischhusen J, Dietmaier W, Hau P, Proescholdt M, Brawanski A, Bogdahn U, Beier CP: CD133 expression and cancer stem cells predict prognosis in high-grade oligodendroglial tumors. Brain Pathol 18: 370-377, 2008
6. Chen S, Song X, Chen Z, Li X, Li M, Liu H, Li J: CD133 expression and the prognosis of colorectal cancer: A systematic review and meta-analysis. PLoS One 8: e56380, 2013

7. Durand A, Labrousse F, Jouvet A, Bauchet L, Kalamarides M, Menei P, Deruty R, Moreau JJ, Fevre-Montange M, Guyotat $\mathrm{J}$ : WHO grade II and III meningiomas: A study of prognostic factors. J Neurooncol 95: 367-375, 2009

8. Favaro R, Appolloni I, Pellegatta S, Sanga AB, Pagella P, Gambini E, Pisati F, Ottolenghi S, Foti M, Finocchiaro G, Malatesta P, Nicolis SK: Sox2 is required to maintain cancer stem cells in a mouse model of high-grade oligodendroglioma. Cancer Res 74: 1833-1844, 2014

9. Galani V, Alexiou GA, Miliaras G, Dimitriadis E, Triantafyllou E, Galani A, Goussia A, Kanavaros P, Trangas T: Expression of stem cell marker Nestin and MicroRNA-21 in meningiomas. Turk Neurosurg 25: 574-577, 2015

10. Galli R, Binda E, Orfanelli U, Cipelletti B, Gritti A, De Vitis $\mathrm{S}$, Fiocco R, Foroni C, Dimeco F, Vescovi A: Isolation and characterization of tumorigenic, stem-like neural precursors from human glioblastoma. Cancer Res 64: 7011-7021, 2004

11. Ghods AJ, Irvin D, Liu G, Yuan X, Abdulkadir IR, Tunici P, Konda B, Wachsmann-Hogiu S, Black KL, Yu JS: Spheres isolated from $9 \mathrm{~L}$ gliosarcoma rat cell line possess chemoresistant and aggressive cancer stem-like cells. Stem Cells 25: 1645-1653, 2007

12. Hadjipanayis CG, Van Meir EG: Brain cancer propagating cells: Biology, genetics and targeted therapies. Trends Mol Med 15: 519-530, 2009

13. Hu D, Wang X, Mao Y, Zhou L: Identification of CD105 (endoglin)-positive stem-like cells in rhabdoid meningioma. J Neurooncol 106: 505-517, 2012

14. Huang M, Zhu H, Feng J, Ni S, Huang J: High CD133 expression in the nucleus and cytoplasm predicts poor prognosis in nonsmall cell lung cancer. Dis Markers 2015:986095, 2015

15. Joo KM, Kim SY, Jin X, Song SY, Kong DS, Lee JI, Jeon JW, Kim MH, Kang BG, Jung Y, Jin J, Hong SC, Park WY, Lee DS, Kim H, Nam DH: Clinical and biological implications of CD133-positive and CD133-negative cells in glioblastomas. Lab Invest 88: 808-815, 2008

16. Jordan CT, Guzman ML, Noble M: Cancer stem cells. N Engl J Med 355: 1253-1261, 2006

17. Kalamarides M, Stemmer-Rachamimov AO, Niwa-Kawakita M, Chareyre F, Taranchon E, Han ZY, Martinelli C, Lusis EA, Hegedus B, Gutmann DH, Giovannini M: Identification of a progenitor cell of origin capable of generating diverse meningioma histological subtypes. Oncogene 30: 2333-2344, 2011

18. Kashihara $H$, Shimada $M$, Kurita N, Iwata $T$, Sato $H$, Kozo $Y$, Higashijima J, Chikakiyo M, Nishi M, Matsumoto N: CD133 expression is correlated with poor prognosis in colorectal cancer. Hepatogastroenterology 61: 1563-1567, 2014

19. Kim K, Ihm H, Ro JY, Cho YM: High-level expression of stem cell marker CD133 in clear cell renal cell carcinoma with favorable prognosis. Oncol Lett 2: 1095-1100, 2011

20. Kondo T, Setoguchi T, Taga T: Persistence of a small subpopulation of cancer stem-like cells in the C6 glioma cell line. Proc Natl Acad Sci U S A 101: 781-786, 2004 
21. Louis DN, Perry A, Reifenberger G, von Deimling A, FigarellaBranger D, Cavenee WK, Ohgaki H, Wiestler OD, Kleihues P, Ellison DW: The 2016 World Health Organization Classification of Tumors of the Central Nervous System: A summary. Acta Neuropathol 131: 803-820, 2016

22. Miraglia S, Godfrey W, Yin AH, Atkins K, Warnke R, Holden JT, Bray RA, Waller EK, Buck DW: A novel five-transmembrane hematopoietic stem cell antigen: Isolation, characterization, and molecular cloning. Blood 90: 5013-5021, 1997

23. Pallini R, Ricci-Vitiani L, Montano N, Mollinari C, Biffoni M, Cenci T, Pierconti F, Martini M, De Maria R, Larocca LM: Expression of the stem cell marker CD133 in recurrent glioblastoma and its value for prognosis. Cancer 117:162174, 2011

24. Palm T, Schwamborn JC: Brain tumor stem cells. Biol Chem 391: 607-617, 2010

25. Phi JH, Park SH, Kim SK, Paek SH, Kim JH, Lee YJ, Cho BK, Park CK, Lee DH, Wang KC: Sox2 expression in brain tumors: A reflection of the neuroglial differentiation pathway. Am J Surg Pathol 32: 103-112, 2008

26. Singh SK, Hawkins C, Clarke ID, Squire JA, Bayani J, Hide T, Henkelman RM, Cusimano MD, Dirks PB: Identification of human brain tumour initiating cells. Nature 432: 396-401, 2004
27. Song WS, Yang YP, Huang CS, Lu KH, Liu WH, Wu WW, Lee YY, Lo WL, Lee SD, Chen YW, Huang PI, Chen MT: Sox2, a stemness gene, regulates tumor-initiating and drug-resistant properties in CD133-positive glioblastoma stem cells. J Chin Med Assoc 79: 538-545, 2016

28. Sulman E, Aldape K, Colman H: Brain tumor stem cells. Curr Probl Cancer 32: 124-142, 2008

29. Tam WL, Ng HH: Sox2: Masterminding the root of cancer. Cancer Cell 26: 3-5, 2014

30. Tang HL, Gong Y, Mao Y, Xie Q, Zheng MZ, Wang DJ, Zhu HD, Wang XC, Chen H, Chen XC, Zhou LF: CD133-positive cells might be responsible for efficient proliferation of human meningioma cells. Int J Mol Sci 13: 6424-6439, 2012

31. Yamamoto S, Tanaka K, Takeda K, Akiyama H, Ichikawa Y, Nagashima Y, Endo I: Patients with CD133-negative colorectal liver metastasis have a poor prognosis after hepatectomy. Ann Surg Oncol 21: 1853-1861, 2014

32. Yu Y, Flint A, Dvorin EL, Bischoff J: AC133-2, a novel isoform of human AC133 stem cell antigen. J Biol Chem 277: 2071120716, 2002

33. Zhao P, Hu M, Zhao M, Ren X, Jiang Z: Prognostic factors for patients with atypical or malignant meningiomas treated at a single center. Neurosurg Rev 38:101-107; discussion 107, 2015 